\title{
PERFORMA PERTUMBUHAN KRABLET KEPITING BAKAU (Scylla olivacea) DENGAN FREKUENSI PEMBERIAN PAKAN BERBEDA PADA STADIA PENDEDERAN
}

\author{
Kamaruddin\#, Usman, dan Asda Laining \\ Balai Penelitian dan Pengembangan Budidaya Air Payau
}

\begin{abstract}
ABSTRAK
Salah satu upaya untuk menekan tingkat kanibalisme dan memicu pertumbuhan krablet kepiting bakau adalah dengan pemberian pakan yang cukup, baik jumlah maupun mutu. Penelitian ini bertujuan mengevaluasi kinerja pertumbuhan dan sintasan krablet kepiting bakau dengan frekuensi pemberian pakan berbeda pada stadia pendederan. Hewan uji berupa krablet kepiting bakau dengan bobot awal $0,037 \pm 0,005 \mathrm{~g}$ dan lebar karapas awal 3,43 $\pm 0,42 \mathrm{~mm}$; menggunakan sembilan unit fiber gelas dengan ukuran masing-masing $1 \mathrm{~m} \times 1 \mathrm{~m} \times 0,5 \mathrm{~m}$. Hewan uji ditebar dengan kepadatan $50 \mathrm{ekor} / \mathrm{m}^{2}$. Perlakuan yang diujicobakan adalah frekuensi pemberian pakan per hari, yaitu: (A) dua kali (pukul 08.00 dan 18.00), (B) tiga kali (pukul 08.00, 13.00, dan 18.00), dan (C) empat kali (pukul 08.00, 13.00, 18.00, dan 23.00). Pakan yang digunakan berupa pelet dengan kandungan protein kasar 46,5\% lemak 8,8\% dan energi total $18,8 \mathrm{MJ} / \mathrm{kg}$. Dosis pakan harian sebanyak 30\%15\%bobot badan secara menurun hingga akhir penelitian. Setelah lima minggu pemeliharaan didapatkan hasil yang menunjukkan bahwa pertumbuhan, sintasan, konsumsi pakan harian, rasio konversi pakan, dan rasio efisiensi protein tidak menunjukkan perbedaan yang nyata $(P>0,05)$ di antara perlakuan. Namun demikian, pemberian pakan empat kali sehari cenderung menunjukkan pertumbuhan yang lebih cepat dan dengan ukuran krablet yang lebih seragam.
\end{abstract}

KATA KUNCl: pertumbuhan; pendederan; frekuensi pemberian pakan; Scylla olivacea; krablet

ABSTRACT: Growth performances of mud crab (Scylla olivacea) crablet on different feeding frequency in nursery stage. By: Kamaruddin, Usman, and Asda Laining

\begin{abstract}
One of techniqueto reduce cannibalism and to stimulate the growth of mud crab is by providing an adequate feed that meet the requirement level of the crablet. The objecive of this study was to evaluatethe growth and survival of crablet fed artificial diet with different feeding frequencies during nursery stage. The treatments were different feeding frequencies namely (A) 2 times (08:00 and 18:00), (B) 3 times (08:00, 13:00, and 18:00) and (C) 4 times (08:00, 13:00, 18:00 and 23:00). Feeding rate was from 30 to $15 \%$ of biomass/day. Feed used in the feeding trial was a dry pellet (1.2 mm size) containing $46.5 \%$ crude protein, $8.8 \%$ lipid and gross energy $18.8 \mathrm{MJ} / \mathrm{kg}$. Mud crab crablet with initial body weight of $0.037 \pm 0.005 \mathrm{~g}$ with carapace width of $3.43 \pm 0.042 \mathrm{~mm}$ were stocked into nine fiber tanks $(1 \mathrm{~m} \times 1 \mathrm{~m} \times 0.5 \mathrm{~m})$ with density of 50 crablets / tank. After 5 weeks of feeding trial, results of the experiment showed that growth rate, survival, feed intake, feed conversion ratio and protein efficiency ratio were not significantly difference $(P>0.05)$ among the treatments. However, growth performance of crablet fed 4 times/day increased and resulted uniformsize of crablet.
\end{abstract}

KEYWORDS: growth; nursery; feeding frequency; Scylla olivacea; crablet

\section{PENDAHULUAN}

Kepiting bakau (Scylla olivacea) adalah salah satu komoditas ekspor dari sektor perikanan yang memiliki harga jual cukup tinggi di tingkat petani. Kepiting bakau ini memiliki potensi besar untuk dibudidaya di

\footnotetext{
* Korespondensi: Balai Penelitian dan Pengembangan Budidaya Air Payau. Jl. Makmur Dg. Sitakka No. 129, Maros 90512, Sulawesi Selatan, Indonesia. Tel.: + (0411) 371544 E-mail: dgbilla@yahoo.com
}

kawasan Asia-Pasifik (Trino \& Rodriguez, 2002). Namun demikian, saat ini produksi kepiting bakau di Indonesia masih didominasi oleh hasil tangkapan dari alam karena kegiatan budidayanya belum berkembang dengan baik. Beberapa faktor yang menyebabkan terhambatnya perkembangan kegiatan budidaya kepiting bakau antara lain ketersediaan benih yang masih mengandalkan hasil tangkapan di alam, ketergantungan penggunaan pakan rucah yang kualitas dan kontinuitasnya rendah, dan tingkat kanibalisme 
kepiting yang tinggi (Usman et al., 2016a). Adanya larangan penangkapan kepiting bakau ukuran tertentu dan induk kepiting betina oleh pemerintah, menyebabkan perlunya kegiatan perbenihan untuk menyuplai kebutuhan benih bagi kegiatan budidaya pembesarannya.

Salah satu masalah dalam kegiatan budidaya kepiting bakau adalah adanya sifat kanibal. Sifat kanibal kepiting bakau mulai meningkat dan persentasenya sangat tinggi terjadi pada stadia krablet karena capitnya telah terbentuk secara sempurna. Selain sifat alaminya, kanibalisme ini juga dipicu oleh adanya perbedaan ukuran yang mencolok di antara individu, serta adanya ketidakcukupan pakan baik kuantitas maupun kualitasnya dalam suatu wadah atau badan air yang terbatas (Folkvord \& Ottera, 1993; Hecht \& Piennar, 1993; Folkvord, 1997). Pada masa pendederan, krablet kepiting bakau biasanya dipelihara dengan kepadatan tinggi untuk menghasilkan jumlah benih yang siap tebar di tambak pembesaran.

Salah satu upaya untuk menekan tingkat kanibalisme dan meningkatkan pertumbuhan krablet kepiting bakau adalah dengan pemberian pakan yang cukup, baik dalam hal jumlah maupun mutu. Selama ini, pada periode pendederan krablet kepiting bakau diberikan pakan berupa ikan rucah segar dan rebon. Namun demikian, pakan ikan rucah memiliki beberapa kelemahan, antara lain cepat rusak, kualitasnya fluktuatif, dan membutuhkan tempat penyimpanan khusus (freezer). Menurut Fielder (2004), keberhasilan pengembangan budidaya kepiting bakau ke depan sangat tergantung pada adanya pakan formula yang ekonomis dan bermutu. Genodepa et al. (2004) melaporkan bahwa larva kepiting bakau memiliki respons dan mampu memanfaatkan pakan buatan (microbound diet). Oleh karena itu, kepiting bakau pada stadia krablet sebaiknya sudah diberikan pakan buatan. Pemberian pakan buatan sejak dini tersebut akan memudahkan pemberian pakan buatan pada kepiting bakau dalam masa pembesarannya.

Beberapa informasi hasil penelitian tentang pakan buatan untuk kepiting bakau, terdata bahwa pada stadia krablet kebutuhan protein dalam pakan adalah 46,9\%47,03\%(Unnikrishnan \& Paulraj, 2010); lemak 5,3\%13,8\% (Sheen \& Wu, 1999; Catacutan, 2002); kolesterol 0,51\%(Sheen, 2000); dan krablet sudah dapat mencerna beberapa bahan hewani dan nabati (Catacutan et al., 2003; Tuan et al., 2006; Truong et al., 2008). Sementara itu, informasi tentang manajemen (dosis dan frekuensi) pemberian pakan buatan pada stadia krablet masih sangat terbatas. Penelitian ini dilakukan untuk mengevaluasi kinerja pertumbuhan krablet kepiting bakau pada stadia pendederan yang diberi pakan buatan dengan frekuensi pemberian pakan yang berbeda.

\section{BAHAN DAN METODE}

Penelitian ini dilakukan di Instalasi Tambak Percobaan Marana Kabupaten Maros, Sulawesi Selatan pada bulan Juni-Juli 2016.

\section{Hewan Uji}

Hewan uji yang digunakan dalam penelitian ini adalah krablet kepiting bakau yang berukuran bobot rata-rata $0,037 \pm 0,005 \mathrm{~g}$ dan lebar karapas 3,43 \pm $0,42 \mathrm{~mm}$ sebanyak 450 ekor. Hewan uji tersebut diperoleh dari hasil pembenihan di Laboratorium Basah Marana, Balai Penelitian dan Pengembangan Budidaya Air Payau (BPPBAP), Maros.

\section{Pakan Uji}

Pakan uji yang digunakan adalah pakan buatan berbentuk pelet dengan ukuran 1-2 mm dengan kandungan protein kasar $46,5 \%$ lemak $8,8 \%$ dan energi total 18,8 MJ/kg; dengan komposisi seperti disajikan pada Tabel 1. Perlakuan yang dicobakan adalah frekuensi pemberian pakan harian yaitu: (A) dua kali (pukul 08.00 dan 18.00), (B) tiga kali (pukul 08.00, 13.00, dan 18.00), dan (C) empat kali (pukul 08.00, 13.00, 18.00, dan 23.00). Dosis pemberian pakan per hari diberikan menurun secara bertahap berdasarkan perkembangan ukuran hewan uji dimulai dari 30\%menurun menjadi 10\% dari bobot badan (Usman et al., 2016b). Pengambilan sisa pakan yang tidak dimakan dilakukan sebelum pemberian pakan berikutnya.

\section{Kondisi Pemeliharaan}

Hewan uji krablet kepiting bakau dipelihara selama lima minggu menggunakan sembilan unit fiber gelas dengan ukuran masing-masing $1 \mathrm{~m} \times 1 \mathrm{~m} \times 0,5 \mathrm{~m}$. Ke dalam wadah tersebut dimasukkan shelter berupa lima potongan waring hitam berukuran $40 \mathrm{~cm} \times 40 \mathrm{~cm}$ untuk memperluas permukaan agar dapat ditempati hewan uji. Hewan uji ditebar dengan kepadatan 50 ekor $/ \mathrm{m}^{2}$. Sampling pertumbuhan dan sintasan hewan uji dilakukan setiap minggu untuk menyesuaikan dosis pemberian pakan. Peubah yang diamati meliputi: sintasan krablet kepiting, laju pertumbuhan, rasio konversi pakan, efisiensi protein, distribusi tingkat keseragaman benih, komposisi kimia tubuh. Untuk mempertahankan kualitas media pemeliharaan agar tetap layak bagi kehidupan hewan uji, maka dilakukan pergantian air sebanyak 20\%30\% setiap hari. Monitoring kualitas air dilakukan terhadap peubah salinitas, suhu air, pH, oksigen terlarut, amoniak nitrogen total (TAN), nitrit, nitrat, alkalinitas, dan besi tersedia. 
Tabel 1. Komposisi bahan dan proksimat pakan uji (\%bobot kering)

Table 1. Ingredient and proximate composition of the experimental diets (\%dry weight)

$\begin{array}{cc}\begin{array}{c}\text { Bahan } \\ \text { Ingredients }\end{array} & \text { Jumlah } \\ \text { Total }(\%)\end{array}$

\begin{tabular}{lc}
\hline Tepung ikan (Fish meal) & 38 \\
Tepung cumi (Squid meal) & 10 \\
Tepung rebon (Mysid meal) & 15 \\
Tepung terigu (Wheat meal) & 17 \\
Tepung tapioka (Tapioca meal) & 5 \\
Tepung rumput laut (Gracilaria sp.) & 3 \\
Minyak ikan (Fish oil ) & 3 \\
Minyak kedelai (Soybean oil) & 1 \\
Vitamin premix ${ }^{1)}$ & 3 \\
Mineral premix ${ }^{2)}$ & 3 \\
Kuning telur (Egg yolk) & 0.5 \\
Lecitine & 1 \\
Carophyll pink & 0.5 \\
$\quad$ Komposisi proksimat (Proximate composition): & \\
- Protein kasar (Crude protein) & 46.5 \\
- $\quad$ Lemak (Lipid) & 8.8 \\
- Serat kasar (Crude fibre) & 2.4 \\
- $\quad$ Abu (Ash) & 10.6 \\
- BETN (NFE) & 31.7 \\
- Energi total (MJ/kg) (Gross energy (MJ/kg) $)^{4)}$ & 18.8 \\
\hline
\end{tabular}

1) Vitamin premix (dalam $1 \mathrm{~kg}$ pakan (in $1 \mathrm{~kg}$ of diet)): vit. A $90.000 \mathrm{IU}$; vit. D3 $30.000 \mathrm{IU}$; vit. K3 $36 \mathrm{mg}$; vit. E $225 \mathrm{mg}$; vit. $\mathrm{B}_{1} 90 \mathrm{mg}$; vit. $\mathrm{B}_{2} 135 \mathrm{mg}$; vit. $\mathrm{B}_{6} 90 \mathrm{mg}$; vit. $\mathrm{B}_{12} 90 \mathrm{mg}$; vit. C $240 \mathrm{mg}$; calcium D-pentathenate $120 \mathrm{mg}$; folic acid $45 \mathrm{mg}$, biotin $300 \mathrm{mg}$, inositol $375 \mathrm{mg}$, nicotinamide $600 \mathrm{mg}$, cholin chloride $450 \mathrm{mg}$;

2) Mineral premix (dalam $1 \mathrm{~kg}$ pakan (in $1 \mathrm{~kg}$ of diet)): $\mathrm{FeCl}_{3} \cdot 4 \mathrm{H}_{2} \mathrm{O} 1660 \mathrm{mg} ; \mathrm{ZnSO}_{4} 100 \mathrm{mg}$; $\mathrm{MnSO}_{4} 67,5 \mathrm{mg} ; \mathrm{CuSO}_{4} 20 \mathrm{mg} ; \mathrm{Kl} 1,5 \mathrm{mg}, \mathrm{CoSO}_{4} \cdot 7 \mathrm{H}_{2} \mathrm{O} 1,0 \mathrm{mg} ; \mathrm{Ca}\left(\mathrm{H}_{2} \mathrm{PO}_{4}\right) 11.000 \mathrm{mg} ;$ $\mathrm{MgSO}_{4} .7 \mathrm{H} 2 \mathrm{O} 13.000 \mathrm{mg} ; \mathrm{K}_{2} \mathrm{HPO}_{4} .8 .000 \mathrm{mg} ;$

3) BETN (Bahan ekstrak tanpa nitrogen) (NFE (Nitrogen free extract))

4) Energi total dihitung berdasarkan nilai konversi untuk protein, lemak, dan BETN berturut-turut 21,3;39,5; dan 17,2 MJ/kg (Gross energy calculation from the determined protein, lipid, and NFE of the diet using conversion coefficiency of 21.3; 39.5; and $17.2 \mathrm{MJ} /$ kg respectivey (Cuzon \& Guillaume, 1997)

\section{Analisis Data}

Penilaian kinerja pertumbuhan dan tingkat pemanfaatan pakan uji oleh hewan uji didasarkan atas beberapa peubah seperti:

Pertumbuhan bobot relatif dihitung dengan formula (Takeuchi, 1988):

$$
\begin{aligned}
& \text { Pertumbuhan RW }\left(\%=\frac{(F W(g)-I W(g)) \times 100}{I W(g)}\right. \\
& \begin{array}{ll}
\text { di mana: } \\
R \quad=\text { bobot relatif } \\
F W \quad=\text { bobot akhir } \\
\text { IW } \quad=\text { bobot awal }
\end{array}
\end{aligned}
$$

Tingkat konsumsi pakan harian dihitung berdasarkan formula (Ozorio et al., 2009):

$$
\mathrm{KPH}(\%)=\frac{\mathrm{TKP}(\mathrm{g}) \times 100}{[(\mathrm{FW}+\mathrm{IW}) / 2] \times \mathrm{LP}(\text { hari })}
$$

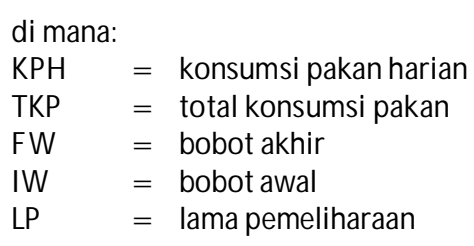

Rasio konversi pakan (FCR) ditentukan mengikuti Unnikrishnan \& Paulraj (2010): 


$$
\mathrm{FCR}=\frac{\text { Jumlah pakan yang diberikan }(\mathrm{g})}{\text { Pertambahan bobot hewan uji }(\mathrm{g})}
$$

Rasio efisiensi protein (REP) ditentukan mengikuti Mohseni \& Ozorio (2014):

$$
\mathrm{REP}=\frac{\text { Pertambahan bobot hewan uji }(\mathrm{g})}{\text { Jumlah protein yang dimakan }(\mathrm{g})}
$$

$$
\text { SR }(\%)=\frac{\text { Jumlah hewan uji akhir penelitian }}{\text { Jumlah hewan uji di awal penelitian }} \times 100 \%
$$

Analisis proksimat pakan dan kepiting dilakukan berdasarkan AOAC (1999) kandungan bahan kering (DM) sampel diperoleh dengan mengeringkannya dalam oven pada suhu $105^{\circ} \mathrm{C}$ selama 16 jam, protein kasar dianalisis dengan micro-Kjeldahl, dan lemak dideterminasi secara gravimetrik dengan ekstraksi chloroform : methanol. Serat kasar dianalisis dengan pemanasan yang disertai pencucian asam dan basa secara bergantian, dan abu dengan pembakaran dalam tanur pada suhu $550^{\circ} \mathrm{C}$ selama 24 jam.

Data kinerja pertumbuhan dan pemanfaatan pakan diuji dengan dianalisis ragam dan uji Beda Nyata Terkecil (BNT) (Steel \& Torrie, 1995). Nilai kualitas air (TAN, nitrit, nitrat, pH, DO, salinitas, dan alkalinitas) dianalisis secara deskriptif.

\section{HASIL DAN BAHASAN}

Performa pertumbuhan krablet dengan frekuensi pemberian pakan berbeda selama lima minggu pendederan disajikan pada Tabel 2. Pada Tabel 2 terlihat bahwa laju pertumbuhan, sintasan, tingkat konsumsi pakan harian, rasio konversi pakan, dan rasio efisiensi protein pakan menunjukkan tidak berbeda nyata antar perlakuan $(P>0,05)$. Namun jika diamati secara seksama, tampak adanya kecenderungan laju pertumbuhan, sintasan, dan tingkat pemanfaatan pakan yang lebih tinggi dengan meningkatnya jumlah frekuensi pemberian pakan, terutama dengan adanya pemberian pakan pada malam hari (pemberian pakan harian empat kali). Pemberian pakan beberapa kali (empat kali) dalam 24 jam memungkinkan kepiting memakan makanan yang lebih segar untuk beberapa kali, sehingga nutrisi yang terkandung di dalam pakan tidak banyak mengalami pencucian dalam air bila dibandingkan pemberian pakan hanya dua kali sehari.

Aktivitas makan krustase berfluktuasi selama 24 jam dan ini mungkin terkait dengan pengaruh dari dalam yang disesuaikan dengan fotoperiodik dan ketersediaan pakan (Boujard \& Leatherland, 1992).

Tabel 2. Performa pertumbuhan krablet kepiting bakau dengan frekuensi pemberian pakan berbeda setelah lima minggu masa pendederan

\begin{tabular}{|c|c|c|c|}
\hline \multirow{2}{*}{$\begin{array}{l}\text { Peubah } \\
\text { Variables }\end{array}$} & \multicolumn{3}{|c|}{ Frekuensi pemberian pakan harian (Daily feeding frequencies) ) $^{*}$} \\
\hline & Dua kali (Two times) & Tiga kali (Thre times) & Empat kali (Four times) \\
\hline $\begin{array}{l}\text { Bobot akhir rata-rata (g/ekor) } \\
\text { Final body weight (g/ind.) }\end{array}$ & $1.017 \pm 0.032^{\mathrm{a}}$ & $1.047 \pm 0.097^{\mathrm{a}}$ & $1.186 \pm 0.112^{\mathrm{a}}$ \\
\hline $\begin{array}{l}\text { Lebar karapas akhir rata-rata } \\
\text { Final carapace width }(\mathrm{mm})\end{array}$ & $17.43 \pm 0.51^{\mathrm{a}}$ & $17.94 \pm 0.93^{\mathrm{a}}$ & $18.67 \pm 0.73^{\mathrm{a}}$ \\
\hline $\begin{array}{l}\text { Sintasan } \\
\text { Survival rate }(\%)\end{array}$ & $60 \pm 6.00^{\mathrm{a}}$ & $68 \pm 11.10^{\mathrm{a}}$ & $68.7 \pm 2.30^{\mathrm{a}}$ \\
\hline $\begin{array}{l}\text { Pertumbuhan bobot relatif } \\
\text { Relative growth rate }(\%)\end{array}$ & $2649 \pm 86^{a}$ & $2,729 \pm 262^{\mathrm{a}}$ & $31,06.3 \pm 330^{a}$ \\
\hline $\begin{array}{l}\text { Konsumsi pakan harian } \\
\text { Daily feed consumption (\%) }\end{array}$ & $8.50 \pm 0.62^{\mathrm{a}}$ & $7.95 \pm 0.82^{\mathrm{a}}$ & $7.51 \pm 0.60^{\mathrm{a}}$ \\
\hline $\begin{array}{l}\text { Total sisa pakan } \\
\text { Total un-eaten feed (g) }\end{array}$ & $29.87 \pm 4.16^{a}$ & $25.41 \pm 4.63^{a}$ & $26.65 \pm 0.72^{a}$ \\
\hline $\begin{array}{l}\text { Rasio konversi pakan } \\
\text { Feed conversion ratio }\end{array}$ & $1.63 \pm 0.14^{\mathrm{a}}$ & $1.51 \pm 0.20^{\mathrm{a}}$ & $1.40 \pm 0.13^{\mathrm{a}}$ \\
\hline $\begin{array}{l}\text { Rasio efisiensi protein } \\
\text { Protein efficiency ratio }\end{array}$ & $1.41 \pm 0.12^{\mathrm{a}}$ & $1.52 \pm 0.17^{\mathrm{a}}$ & $1.69 \pm 0.14^{\mathrm{a}}$ \\
\hline
\end{tabular}

Table 2. Growth performance of mud crab crablet with different feeding frequencies after 5 weeks of nursery rearing

Semua perubah yang diamati belum menunjukkan adanya perbedaan yang nyata $(P>0,05)$ di antara perlakuan All variable was evaluated not significant different $(P>0.05)$ among the treatments 
Namun demikian, tingkat pemanfaatan pakan kaitannya dengan frekuensi/waktu pemberian pakan juga sangat tergantung pada sifat dan cara makan, laju pengosongan lambung, serta puncak aktivitas makan hewan secara alami yang saling memengaruhi dengan aktivitas enzim dengan pengontrolan hormon dan sistem syaraf (Bolliet et al., 2002; De Pedro \& Bjornsson, 2002; Sanchez-Vazquez \& Madrid, 2002). Kepiting bakau tergolong hewan air yang cenderung aktif makan pada malam hari (nocturnal). Pada pengamatan secara visual, kepiting bakau ini banyak berkeliaran pada malam hari dan relatif cepat responsnya pada pakan jika diberikan pada malam hari dibandingkan pemberian pakan pada siang hari. Hal ini juga yang kemungkinan menyebabkan krablet kepiting bakau yang mendapat pemberian pakan pada malam hari (pemberian pakan empat kali sehari) cenderung memiliki performa pertumbuhan dan pemanfaatan pakan yang lebih baik (meskipun belum berbeda nyata) dibandingkan dengan krablet yang diberi pakan pada siang hari (pemberian pakan dua dan tiga kali sehari). Bolliet et al. (2002) juga melaporkan bahwa ikan African catfish, Heterobranchus longifilis, yang diberi pakan pada waktu malam ternyata tumbuh lebih baik daripada yang diberi pakan pada siang hari. Hal yang sama juga terjadi pada ikan Indian catfish, Heteropneuster fossilis (Sundararaj et al., 1982). Ikan characin, Piarachus brachypomus yang diberi pakan secara kontinu pada waktu malam (pukul 20.30-08.30) tumbuh lebih baik daripada yang diberi pakan pada siang hari (pukul 08.30-20.30) (Baras et al., 1996). Hal ini menunjukkan bahwa ikan/krustase golongan nokturnal umumnya memiliki laju pertumbuhan yang lebih tinggi bila diberi pakan pada malam hari (gelap) dibandingkan jika diberi pakan pada siang hari (terang).

Hasil analisis sintasan pada hewan uji terlihat bahwa terjadi penurunan sintasan setiap minggu untuk semua perlakuan, kecuali pada minggu keempat dan kelima pada perlakuan pemberian pakan empat kali sehari tidak terjadi penurunan sintasan (Gambar 1). Pada umumnya kematian terjadi karena kanibalisme antar individu utamanya ketika terjadi moulting, karena krablet yang sedang atau baru selesai moulting kondisinya sangat lemah dan terlihat putih, serta kemungkinan adanya bau yang merangsang sehingga menarik perhatian bagi krablet lain yang berukuran lebih besar/lebih aktif.

Adanya sifat kanibalisme kepiting menyebabkan sifat soliter individu yang berukuran kecil semakin tinggi ketika dipelihara bersama dengan individu berukuran lebih besar. Pemberian pakan yang jumlahnya melebihi jumlah individu krablet kepiting dalam setiap wadah, lebih memungkinkan untuk mengonsumsi pakan yang lebih segar pada pemberian beberapa kali dibandingkan pada pemberian hanya dua kali. Adanya keragaman ukuran yang cukup besar (Gambar 2), juga salah satu pemicu sifat kanibalisme. Seperti yang dilaporkan Hseu et al. (2003) bahwa pada

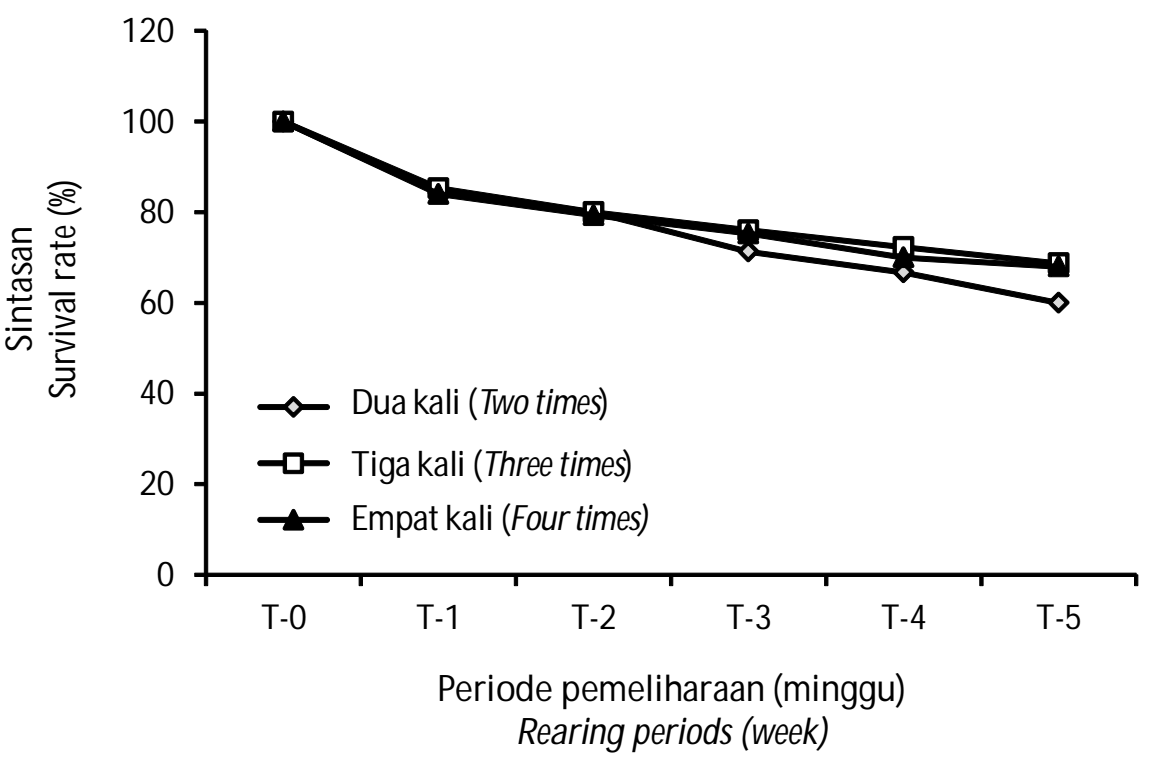

Gambar 1. Pola sintasan krablet kepiting bakau dengan frekuensi pemberian pakan yang berbeda selama lima minggu masa pendederan

Figure 1. Survival rate pattern of mud crab crablet with different feeding frequencies for 5 weeks of nursery rearing 


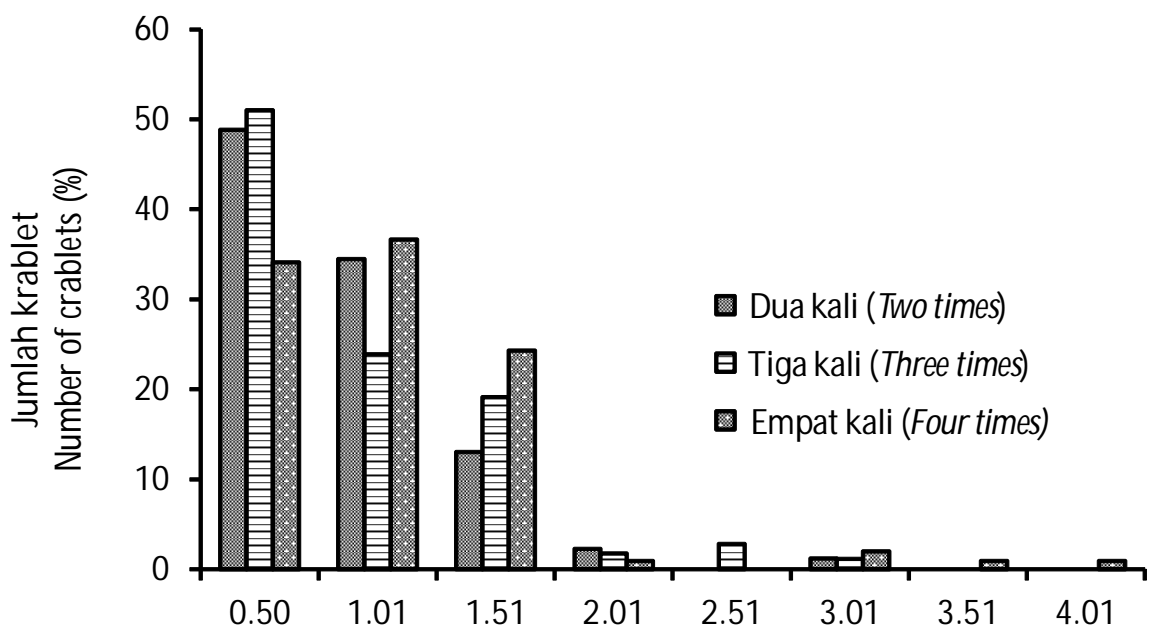

Kelompok ukuran bobot krablet Weight group of crablets $(\mathrm{g})$

Gambar 2. Distribusi ukuran bobot krablet kepiting bakau dengan frekuensi pemberian pakan berbeda setelah lima minggu masa pendederan

Figure 2. Distribution of mud crab crablet body weight with different feeding frequencies after 5 weeks of nursery rearing

dasarnya faktor kanibalisme ini timbul oleh adanya naluri sifat dominan dari suatu individu terhadap individu lain yang diakibatkan oleh perbedaan kemampuan mendapatkan makanan dan laju pertumbuhan, meskipun makanan diberikan secara ad libitum.

Distribusi ukuran krablet dengan frekuensi pemberian pakan berbeda setelah pemeliharaan selama lima minggu disajikan pada Gambar 2. Pada Gambar 2 tersebut terlihat bahwa ukuran krablet terdistribusi mulai dari $0,5 \mathrm{~g}$ hingga $4 \mathrm{~g}$. Secara deskripitf, perlakuan frekuensi pemberian pakan empat kali cenderung mendominasi ukuran krablet yang lebih besar, meskipun ukuran 2,5 g mendominasi frekuensi pemberian pakan tiga kali. Terlepas dari jumlah konsumsi pakan harian, kepiting yang mendapat pemberian pakan beberapa kali akan memperoleh pakan yang lebih berkualitas (padat nutrisi dan tingkat pencucian pakan dalam air lebih rendah) dibandingkan dengan yang diberi pakan dengan frekuensi lebih sedikit. Pakan pelet yang diberikan memiliki daya tahan dalam air cukup lama (> 12 jam), sehingga meskipun pakan hanya diberikan dua kali sehari, keberadaan pakan dalam bak tetap ada hampir 24 jam (pengambilan

Tabel 3. Komposisi proksimat tubuh (\%bahan kering) krablet kepiting bakau dengan frekuensi pemberian pakan berbeda setelah lima minggu masa pendederan

Table 3. Whole body proximate composition (\% dry weight) of mud crab crablet after 5 weeks of nursery rearing

\begin{tabular}{lccc}
\hline \multirow{2}{*}{$\begin{array}{c}\text { Nutrien } \\
\text { Nutrient }\end{array}$} & \multicolumn{2}{c}{$\begin{array}{c}\text { Frekuensi pemberian pakan harian } \\
\text { Daily feeding frequencies }\end{array}$} \\
\cline { 2 - 4 } & $\begin{array}{l}\text { *) } \\
\text { Dua kali (Two times) }\end{array}$ & Tiga kali (Thrœetimes) & Empat kali (Four times) \\
\hline Protein kasar (Crude protein) & $38.1 \pm 0.1^{\mathrm{a}}$ & $37.6 \pm 0.6^{\mathrm{a}}$ & $37.3 \pm 1.6^{\mathrm{a}}$ \\
Lemak (Lipid) & $7.9 \pm 0.8^{\mathrm{a}}$ & $8.3 \pm 0.5^{\mathrm{a}}$ & $9.1 \pm 1.0^{\mathrm{a}}$ \\
Serat kasar (Crude fibre) & $9.5 \pm 1.5^{\mathrm{a}}$ & $9.7 \pm 0.4^{\mathrm{a}}$ & $8.3 \pm 0.9^{\mathrm{a}}$ \\
Abu (Ash) & $29.8 \pm 0.4^{\mathrm{a}}$ & $29.4 \pm 0.3^{\mathrm{ab}}$ & $28.6 \pm 0.3^{\mathrm{b}}$ \\
BETN (NFE) & $14.7 \pm 0.7^{\mathrm{a}}$ & $15.0 \pm 0.8^{\mathrm{a}}$ & $16.8 \pm 1.9^{\mathrm{a}}$ \\
\hline
\end{tabular}


sisa pakan hanya dilakukan dua kali sehari yaitu sebelum pemberian pakan pagi hari dan sebelum pemberian pakan sore/petang hari). Ukuran krablet yang diperoleh dari pendederan selama lima minggu ini secara umum sudah dapat menghasilkan yuwana yang siap ditebar ke tambak pembesaran.

Komposisi proksimat total tubuh krablet dengan frekuensi pemberian pakan berbeda disajikan pada Tabel 3. Pada Tabel 3 terlihat bahwa kadar protein, lemak, serat kasar, dan bahan ekstrak tanpa nitrogen tubuh krablet relatif sama untuk semua perlakuan. Namun kadar abu krablet yang diberi pakan empat kali sehari lebih rendah dan berbeda nyata $(P<0,05)$ dibandingkan dengan kadar abu pada krablet yang diberi pakan dua kali sehari. Hal ini menunjukkan bahwa krablet yang diberi pakan empat kali sehari lebih gemuk dibandingkan dengan yang diberi pakan dua kali sehari.

Selama pemeliharaan krablet kepiting bakau dilakukan penyiponan sisa pakan sebelum pemberian pakan berikutnya, serta pergantian air sebanyak $20 \%$ $30 \%$ per hari. Nilai peubah kualitas air yang terukur pada setiap perlakuan tidak menunjukkan variasi yang tinggi dengan nilai kisaran yaitu ;salinitas 26-30 ppt; suhu air $24,5^{\circ} \mathrm{C}-28,3^{\circ} \mathrm{C}$; pH 7,3-7,8; oksigen terlarut 4,40-5,41 mg/L; amoniak nitrogen total (TAN) 0,0796$1,3821 \mathrm{mg} / \mathrm{L}$; nitrit 0,0389-2,6262 mg/L; nitrat 0,3247$6,0394 \mathrm{mg} / \mathrm{L}$; alkalinitas 121,2-188,4 mg/L; dan besi tersedia 0,0010-0,0045 mg/L. Nilai kisaran peubah kualitas air tersebut cukup layak bagi kehidupan krablet kepiting bakau (Christensen et al., 2005).

\section{KESIMPULAN}

Kinerja pertumbuhan krablet kepiting bakau tidak dipengaruhi oleh frekuensi pemberian pakan sebanyak 2-4 kali sehari. Namun demikian, pemberian pakan empat kali sehari cenderung memberikan kinerja pertumbuhan yang meningkat.

\section{DAFTAR ACUAN}

AOAC International. (1999). Official methods of analysis. $16^{\text {th }}$ ed. Association of Official Analytical Chemists International, Gaithersberg, Maryland. USA, $1141 \mathrm{pp}$.

Baras, E., Melad, C., Grigard, J.C., \& Thoreau, X. (1996). Comparison of food conversion by pirapatinga, Piaractus brachypomus under different feeding time. The Progressive Fish-Culturist, 58, 59-61.

Bolliet, V., Azzaydi, M., \& Boujard, T. (2002). Effect of feeding time on feed intake and growth. In Houlihan, D., \& Jobling, M. (Eds.). Food Intake in Fish. Oxford, Blackwell Science, p. 233-249.
Boujard, T., \& Leatherland, J.F. (1992). Circadian rhythms an feeding time in fishes. Enviromental Biology of Fish, 35, 109-131.

Catacutan, M.R. (2002). Growth and body composition of juvenile mud crab, Scylla serrata, fed different dietary protein and lipid levels and protein to energy ratios. Aquaculture, 208, 113-123.

Catacutan, M.R., Eusebio, P.S., \& Teshima, S. (2003). Apparent digestibility of selected feedstuffs by mud crab, Scylla serrata. Aquaculture, 216, 253-261.

Christensen, S.M., Macintosh, D.J., \& Phuong, N.T. (2005). Pond production of the mud crab Scylla paramamosain (Estampador) \& S. olivacea (Herbst) in The Mekong Delta, Vietnam, using two different supplementary diest. Aqua. Res., 35, 10131024.

Cuzon, G., \& Guillaume, J. (1997). Energy and protein: energy ratio. Crustacean Nutrition-Advances in Word Aquaculture VI. In D'Abraamo, L., Conklin, D., \& Akiyama, D. (Eds.). World Aquaculture Society, Los Angeles. USA, p. 51-70.

De Pedro, N., \& Bjornsson, T. (2002). Regulation of food intake by neuropeptides and hormones. In Houlihan, D., \& Jobling, M. (Eds.). Food Intake in Fish. Oxford, Blackwell Science, p. 250-268.

Fielder, D. (2004). Crab aquaculture scoping study and workshop. In Allan, G., \& Fielder, D. (Eds.). Mud crab aquaculture in Australia and Southeast Asia. Proceedings of the ACIAR Crab Aquaculture Scoping Study and Workshop, 28-29 April, Joodooburri Conference Centre, Bribie Island. ACIAR Working Paper No. 54. Australian Centre for International Agricultural Research, Canberra. Australia, p. 10-30.

Folkvord, A. (1997). Otogeny of cannibalism in larva and juvenile fishes with special emphasis on Atlantic cod. In Chambers, R.C., \& Trippel, E.A., (Eds.). Early life history and Recruitment in fish populations. Chapman \& Hall. London, p. 251-278.

Folkvord, A., \& Ottera, H. (1993). Effects of initial size distribution, day length and feeding frequency on growth, survival and cannibalism in juvenil Atlantic cod (Gadus morhua). Aquaculture, 114, 243260.

Genodepa, J., Zeng, C., \& Southgate, P.C. (2004). Preliminary assessment of a microbound dietas an Artemia replacement for mud crab, Scylla serrata, megalopa. Aquaculture, 36, 497-509

Hecht, T., \& Pienaar, A.G. (1993). A review of cannibalism and its implications in fish larvi culture. J. World Aqua. Soc., 24, 246-261.

Hseu, J.R., Lu, F.I., Su, H.M., Wang, L.S., Tsai, C.L., \& Hwang, P.P. (2003). Effect of exogenous triptophan on cannibalism, survival and growth in juvenile 
grouper, Epinephelus coioides. Aquaculture, 218, 251263.

Mohseni, M., \& Ozorio, R.O.A. (2014). Effects of dietary L-carnitine level on growth performance, body composition and antioxidant status in beluga (Huso huso L. 1758). Aquaculture Nutrition, 20, 477-485.

Ozorio, R.O.A., Valente, L.M.P., Correia, S., PousaoFerreira, P., Damasceno-Oliveira, A., Escorcia, C., $\&$ Oliva-Teles, A. (2009). Protein requirement for maintenance and maximum growth of two-banded seabream (Diplodus vulgaris) juveniles. Aquaculture Nutrition, 15, 85-93.

Sanchez-Vazquez., F.J., \& Madrid, J.A. (2002). Feeding anticipatory activity. In Houlihan, D., \& Jobling, M. (Eds.). Food Intake in Fish. Oxford, Blackwell Science, p. 216-232.

Sheen, S-S. (2000). Dietary cholesterol requirement of juvenile mud crab Scylla serrata. Aquaculture, 18, 277-285.

Sheen, S., \& Wu, S. (1999). The effects of dietary lipid levels on the growth response of juvenile mud crab Scylla serrata. Aquaculture, 175, 143-153.

Stell, R.G.D. \& Torry, J.H. (1995). Prinsip dan prosedur statistika. Alih bahasa: Bambang Sumantri. Gramedia Pustaka Utama. Jakarta, $748 \mathrm{hlm}$.

Sundararaj, B.I., Nath, P., \& Halberg, F. (1982). Circadian meal timing in relation to lighting schedule optimizes catfish body weight gain. Journal of Nutrition, 112, 1085-1097.

Takeuchi, T. (1988). Laboratory work-chemical evaluation of dietary nutrient. In Watanabe, T. (Ed.).
Fish Nutrition and Mariculture. Department of Aquatic Bioscience, Tokyo University of Fisheries. Japan, p. 179-233.

Trino, A.T., \& Rodriguez, E.M. (2002). Pen culture of mud crab Scylla serrata in tidal flats reforested with mangrove trees. Aquaculture, 211, 125-134.

Truong, P.H., Anderson, A.J., Mather, P.B., Paterson, B.D., \& Richarson, N.A. (2008). Effect of selected feed meals and starches on dietdigestibility in the mud crab, Scylla serrata. Aquaculture Research, 39, 1778-1786.

Tuan, V., Anderson, A., Luang-van, J., Shelley, C., \& Allan, G. (2006). Apparent digestibility of some nutrient sources by juvenile mud crab, Scylla serrata (Forskal 1775). Aquaculture Research, 37, 359-365.

Unnikrishnan, U., \& Paulraj, R. (2010). Dietary protein requirements of giant mud crab Scylla serrata juveniles fed isoenergetic formulated diets having grade protein levels. Aquaculture Research, 41, 278-294.

Usman, Kamaruddin, \& Laining, A. (2016a) Pengaruh kadar triptopan pakan terhadap pertumbuhan dan sintasan krablet kepiting bakau, Scylla serrata selama masa pendederan. Balai Pnelitian dan Pengembangan Budidaya Air ayau, Maros, $23 \mathrm{hlm}$. (In press).

Usman, Kamaruddin, Palinggi, N.N., \& Laining, A. (2016b). Performa pertumbuhan krablet kepiting bakau, Scylla olivacea, pada pemberian dosis pakan berbeda selama masa pendederan. Laporan Balai Penelitian dan Pengembangan Budidaya Air Payau, Maros, $13 \mathrm{hlm}$. (In-press). 